\title{
THE INVISIBLE BOUNDARIES IN THE CITY
}

\author{
Nicola Siddi \\ University of Turin. Torino, Italy. Email: nicola.siddi[at]unito.it
}

Abstract

1. Perhaps physical frontiers are less important since somehow the world has become a global entity, in which information passes through the physical walls.

Many of them have been destroyed (Berlin) and some others such as that of Cyprus resist, but they are certainly less effective than in the past. The major concern of the future is the identification of invisible borders within the cities.

It is difficult to identify exclusion, and marginalization is hiding within the cities, even in the weal- thiest ones.

The spaces of the cities have invisible borders, but they are not easy to cross.

2. An MIT study (Xu Y, Belyi A, Santi P, Ratti C. 2019) highlights these problems after processing data on human movements, social networks connections and the socioeconomic status of people, the document proposes two indices to measure segregation in Singapore.

The index segregation of communication measures the relationship between people within each so- cial network, considering the frequency of communication and the socio-economic attributes of each person.

The physical segregation index indicates the social exposure which people have towards each other belonging to similar and different socio-economic groups as they move more and more around the city.

3. The MIT study shows how it is possible, through the management of big data, to be able to bring out invisible marginalization situations which can not be seen in other ways.

4. The "documedial process" (Ferraris, Paini, 2018) in which the digital breakthrough has transformed the city, allows not only to bring out areas of border and exclusion but lays the foundations for an analysis of reality capable of highlighting cultural isolation.

\section{Keywords}

invisible; boundaries; segregation; marginalization; big data; exclusion; border; cultural isolation; digital breakthrough; documedial process

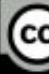

This work is licensed under a $\underline{\text { Creative Commons «Attribution» } 4.0 \text { International License }}$ 


\section{НЕВИДИМЫЕ ГРАНИЦЫ В ГОРОДЕ}

\section{Сидди Никола}

Туринский университет. Торино, Италия. Email: nicola.siddi[at]unito.it

\section{Аннотация}

В современном мире физические границы становятся все менее важны, поскольку в глобализированном мире информация проходит через физические стены. Многие из этих стен были разрушены (в Берлине, например), а другие, например на Кипре, еще сопротивляются, но и они, безусловно, стали менее эффективны, чем в прошлом.

Основная задача будущего - выявление невидимых границ внутри городов. При этом выявить изоляцию бывает довольно трудно, а в городах, даже в самых благополучных, скрывается маргинализация. Пространства городов имеют невидимые границы, но их нелегко пересечь.

Исследуя эти проблемы, ученые Массачусетского технологического института (Xu Y, Belyi A, Santi P, Ratti C. 2019), обработали данных о передвижениях людей, их социально-экономическом статусе и связях в социальных сетях, и предложили два индекса для измерения сегрегации в Сингапуре.

Индекс сегрегации общения измеряет отношения между людьми в каждой социальной сети, учитывая частоту общения и социально-экономические характеристики каждого человека.

Индекс физической сегрегации показывает, как люди, принадлежащих к схожим и разным социально-экономическим группам, становятся открыты друг для друга по мере того, как они все больше и больше перемещаются по городу.

Исследование показывает, как с помощью управления большими данными можно выявить невидимые ситуации маргинализации, которые нельзя увидеть другими способами.

«Документированный медиапроцесс» (Ferraris, Paini, 2018), в ходе которого цифровой прорыв изменил город, позволяет не только выявить области границ и отчуждения, но и закладывает основы для способного выявить культурную изоляцию анализа реальности.

\section{Ключевые слова}

невидимый; границы; сегрегация; маргинализация; мега данные; исключение; граница; культурная изоляция; цифровой прорыв; документальный процесс

Это произведение доступно по лицензии Creative Commons «Attribution» («Атрибуция») 4.0 Всемирная 


\section{INTRODUCTION}

Because they lead my people astray, saying, "Peace," when there is no peace, and because, when a flimsy wall is built, they cover it with whitewash, 11 therefore tell those who cover it with whitewash that it is going to fall. Rain will come in torrents, and I will send hailstones hurtling down, and violent winds will burst forth. When the wall collapses, will people not ask you, "Where is the whitewash you covered it with? Therefore this is what the Sovereign Lord says: In my wrath I will unleash a violent wind, and in my anger hailstones and torrents of rain will fall with destructive fury. I will tear down the wall you have covered with whitewash and will level it to the ground so that its foundation will be laid bare. When it falls, you will be destroyed in it; and you will know that I am the Lord.

Ez. 13, 10-14

Perhaps physical frontiers are less important since somehow the world has become a global entity which information crosses physical walls.

Many of them have fallen (Berlin) and some as that of Cyprus resist, but they are certainly less effective than in the past.

Already in the Hole Bible, in the passage placed at the beginning, in some way, it was highlighted how the walls are destined to fall to the detriment of those who built them and even the plaster of mota (mud) of which Ezekiel speaks, will only serve to deceive people of Israel, but will fail to keep the wall from falling.

\section{PHYSICAL BARRIER}

The most famous physical barrier between two nations actually indicates the fragility and evanescence of the border. The wall between Mexico and the United States, often used as a political slogan, is actually reduced to a symbol of division rather than a real barrier, which unfortunately remains so only for desperate migrants in search of the American dream.

The wall reality, under construction, started in the Obama era, exalted in the Trump era and still under construction, is much more complex that political rhetoric and becomes one of the factors on which US Mexican economic relations are based. As Andrew Selee, president of the Migration Policy Institute argues, that frontier that goes beyond the wall makes the two nations indivisible. The digitalization that has allowed globalization has brought to the surface surprising relationships such as the sharing of the airport in the sister cities of San 


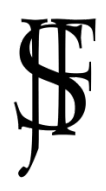

Diego and Tijuana, the rescue of many American companies by Mexican entrepreneurs, the cultural contamination at the film, sports and culinary level, and the million Americans who moved that revive Mexican towns. We can say that, wall or no wall, deeply intertwined social, economic, business, cultural, and personal relationships mean the US-Mexico border is more like a seam than a barrier, weaving together two economies and cultures.

Don Winslow (an American writer) dedicated a trilogy of novels and a short story to the wall with Mexico and the criminal activities they develop on the borders. In the last novel he ascribes to the thoughts of Keller (protagonist of the trilogy): «but there is no wall, neither here nor there, he thinks smiling. And there never will be. A border is something that divides us, but also unites; There can be no wall, just as there is no wall that divides the human soul between its positive and negative impulses» (Winslow, 2019).

\section{INVISIBLE BORDERS}

The greatest concern of the future is the identification of invisible borders within cities. These frontiers are determined by the exclusion that we generally define as social and we define as the inability to access a particular service or good in general. The exclusion we want to deal with, has contents and expresses much wider implications than its common dignity. In this regard, Marc Augé offers a broad and comprehensive analysis of this term.

«Exclusion, therefore. This concept undoubtedly underpins the existence of an interior and an exterior: one is excluded from the inside and finds oneself outside, on the outside. This exterior can be understood in a physical sense. I am referring to the myriad of individuals who flock to the frontiers of the developed world, often at the cost of their own lives, to the boats that regularly capsize at sea, the drama of the escape of excluded individuals, kept out of what in their eyes represents the place. of development, of the possibility of being saved if only they will be able to access it» (Augé, 2007, p. 16).

With these words Augé describes what he calls physical exclusion, the impossibility of entering a country other than the one of origin, this physical exclusion is refoulement at sea, detention in refugee camps, arrest for secrecy. This first aspect, which we will not deal with in any case, is perhaps the bloodiest, from which suffering and death derive, but it is not the last obstacle for those who manage to enter the developed world. The second obstacle is sociological exclusion as Augé defines it: "there is also exclusion in a sociological sense, a social exclusion: within rich countries there are those who do not benefit or benefit little from this wealth, there are who does not have access to a job, to the resources necessary to live.

This group includes many black people who have managed to escape from the poor regions of the planet, passing from the first to the second type 
of exclusion. This second marginalization gathers a wider "audience" than the first as there are also natives in financial difficulties, with social problems, and often the elderly, the sick, the disabled, the unschooled and the unemployed.

As Augé states, «it would be too easy, as well as reductive, to circumscribe the phenomenon of social exclusion to the opposition between the center and the periphery: in the same way in which the periphery is not composed only of excluded people - in fact, very rich peripheries exist - often the center the city is hosting excluded people of all kinds. From this point of view, therefore, the notion of exclusion is a clearly sociological notion. It can also involve other aspects relating to the administrative and political order» (Augé, 2007, p. 17).

Linked to this, Augé's analysis includes a synonym for exclusion: marginalization. This term is linked to the physicality of places, in fact, «to lead to the margins» means, in an urban setting, to lead to the periphery. The term periphery is considered negative precisely because it is linked to marginalization. This has not always been the case, in the 60 s and 70 s of the twentieth century, the periphery was a symbol, certainly not of wealth, but of dignity and modern living.

The problem and decline of these places began in the 80s with the advent of economic crises and the resulting unemployment, producing social and site exclusion. In French there is a term that perfectly identifies this phenomenon: cité. In this cité, second generation immigrants live in France who are not marginalized by urban imposition, but on an economic and above all school level. As Augé argues, «he who is defeated by the system, he who does not adapt to the school system or the economic system, is marginalized» (p. 19). Spatial marginalization therefore becomes only a consequence of a cultural, social and economic marginalization. The different meaning of cité and ville has historical and implicit roots in the French language. The ville is a concrete and material place while the cité is a mental representation. In the French language recently the meaning of cité «mostly refers to the squalid and desolate areas that host less affluent fringes on the outskirts of the city» (Sennett, 2018, p. 11).

But the meaning to which Augé refers also maintains the original meaning as from these peripheral places emerge cultural realities such as Rap and other artistic manifestations. As Augé states, «not all the boys from the suburbs, in fact, are part of gangs of criminals. Our information system too often treads its hand on what is wrong, on the spectacular implications of failure, and has tended to silence everything that does not represent a problem, everything that works more or less well. The banlieue is full of young people who make it and others who manage to get out of disadvantaged situations. Microculture is also the original thing that is created in those places: it may 


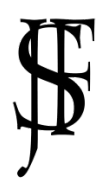

happen that young people do not identify themselves either in their remote origins (Morocco, Algeria, Mali etc.) or in their acquired country, but they feel they have not found their place» (Augé, 2007, p. 25).

These places, especially in this pandemic period, have highlighted the phenomenon of the digital divide linked to economic reasons and the lack of infrastructure. The inability of families to buy computers, tablets or smartphones suitable for distance learning and the low diffusion of fiber in the peripheral areas of cities has once again placed many young students at a disadvantage.

This story has highlighted a double ghettoization, the spatial and the digital one. However, digital, like any tool, also has its positive version which in this case is expressed in the possibility of unmasking exclusion.

\section{SINGAPORE CALLING}

It difficult to identify exclusion marginalization is hiding within the cities, even in the wealthiest ones. The spaces of the cities have invisible borders, but not therefore easily crossable.

An MIT study (Xu, Belyi, Santi \& Ratti, 2019) highlights these problems after processing data of human movements, social network connections and people's socioeconomic status, the document proposes two indices to measure segregation in Singapore. The communication segregation index measures the connection between people within each individual social network, considering the frequency of contacts and the socio-economic attributes (linked to the value of the residential properties) of each person.

The physical segregation index measures the social exposure that individuals have towards people belonging to similar and different socioeconomic groups as they move more around the city. The study was born from the intuition that while cities are places of meeting opportunities on a cultural, social and economic level, they can also be places of marginalization. The meeting of people who have different ethnic, cultural and socio-economic backgrounds is a sign of differences that make the city interesting, but which can turn into alienation.

The analysis of the workplace and residence provides us with a too static division mapping that often does not identify the urban social reality. Carlo Ratti, in fact, states: «Cities are rather dynamic, and we need better tools to understand people's exposures to other social groups as they interact with each other in the city and in social networks» (Singapore Calling).

The MIT study substantially highlights how it is possible, through the management of big data, to be able to bring out otherwise invisible situations of marginalization. «This is the first study to propose a methodology to quantify segregation in a coupled physical-social space. It allows us to go beyond 
the traditional measures of residential segregation that are expressed through static spatial terms» (Singapore Calling), comments by Paolo Santi, a Research Scientist at the MIT Senseable City Lab. By better understanding social segregation in cities, the ultimate goal is to find ways to bring people together, creating vibrant and diverse cities.

The documentary process (Ferraris \& Paini, 2018) in which the digital turning point has transformed the city not only allows for the emergence of border and exclusion areas but lays the foundations for an analysis of reality capable of highlighting the cultural isolation it has strong analogies with the emergence of criminal activities. He believes that crime is an emergency, not so much from the point of view of urgency, but in relation to its emergence of the evolution of the social reality deriving from culture, place, socio-economic context and historical moment.

The city, as you can easily guess, offers more opportunities for crime. This suggestion is confirmed by the data: taking as an example the region and the Italian city where I come from, Turin has a $31 \%$ higher crime rate than the regional territory (Piedmont 5,155 out of 100,000 inhabitants of Turin 6,763 out of 100,000 inhabitants). As noted by Geoffrey West (2017), city infrastructures have a sublinear ratio with respect to the demographic figure of 0.85 , while in the socio-economic context, the ratio is superlinear equal to 1.15 . This means that if the length of the roads, the quantity of electric cables, the diffusion of sewers increases with an index of 0.85 with the increase of the population, wages, wealth, flu cases and the incidence of crime increase to an extent. of 1.15 .

Once we have verified that the city, in addition to being the privileged place for the spread of culture, is also the center of crime, we can ask ourselves the following question: to what extent does the city affect crime and how does delinquency affect the city? The question is complex as the urbs (the physical part of the city) and the civitas (the citizens) are "woven" together according to the definition of Edgar Morin (2015). It is not a question of researching the laws that define the relationship between daily life (therefore crime) and the city, but of using a method that allows us to deal with uncertainty and verify how they affect each other. The modern shape of the world (including the criminal one) is given by the complex interrelationships between society, city and global computerization that are characterized by heterogeneity, the network, interdependence and the ability to adapt. To understand, manage and possibly contribute to changing society, we must change the paradigm by considering two essential points of contemporaneity: the exponential acceleration of changes and the network.

While taking into consideration Morin's reflections on the non-exhaustive use of big data, we believe it is important to point out that their use can 


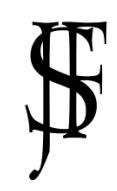

Журнал Фронтирных Исследований. 2021. No 1 | ISSN: 2500-0225

Конфигурация города | Doi: https://doi.org/10.46539/jfs.v6i1.257

play a complementary role in the context of complex analyzes. An example of this is the case of Singapore that we described earlier.

We have analyzed various forms of borders that the city can raise, some limits are physical and appear to be less dangerous and, in any case, less significant than immaterial borders. Physical walls are, if not demolished, at least overcome by digital tools which are able to reveal pockets of marginalization that are difficult to bring to the surface otherwise, but at the same time the medialization of reality involves in turn the emergence of digital segregation that however, it somehow damages itself and its elimination depends on political decisions.

\section{PANDEMIC}

In this pandemic period we believe it becomes interesting to underline how digital barriers can play a positive role. For greater protection, security and control of Covid19 we have very effective tools linked to our smartphones. In this regard, we would like to remind you that an app called "fluphone" was developed on a European level in 2011 and was not used for reasons related to privacy. Without entering into the controversy that arose from the use of data by China, South Korea and Singapore - a use that has had an indisputable success - we remember how willing we are to pour our personal data for futile reasons on social networks (Facebook, Twitter, TikTok, Instagram) without any control and then suddenly worry about our privacy in the event of a health emergency.

In any case, on the use of technology and innovation, it is good to remember how we discovered the reason for the infection and consequently also the nature of the spread of the cholera bacterium which, in the nineteenth century, had severely tested the cities of London and New York.

In 1854 in Soho (Johnson, 2006) (London suburb), one of the major outbreaks of cholera developed. In this area of the city lived a doctor, John Snow, who for four or five years had already claimed that cholera was transmitted through contaminated water, but without being able to convince anyone. The public health authorities had largely ignored his words. He had observed that the inhabitants near a particular water pump died more frequently. Snow resided right nearby and had suspected that such a concentrated outbreak could have only one source, which many drew from, as the infection did not have the traditionally slow progression that was expected.

To analyze the situation he used Henry Whitehead, a local minister who was by no means a man of science, but was incredibly socially connected. The latter in fact knew the whole neighborhood and provided information on the inhabitants so that Snow could "trace" the cases of people who had drunk the water from the pump. The next and final step was to draw a map that repre- 
sented in a way the situation was clear. The direct consequence was that, by convincing the population to boil water, the outbreak was exhausted and in the following years London and other large cities began to equip themselves with sewers to prevent the aquifers from being subject to pollution. Snow was not the only reason that pushed cities to equip themselves with hygienic technologies, but it has certainly contributed to improving life in urban areas. life, but certainly the clever use of Dr. Snow's map shows us how even a simple app could help us in case i n which danger once again loomed on our global smart cities.

\section{CONCLUSION}

In conclusion, our evolution and our survival have depended - starting from two hundred thousand years ago, just when Homo sapiens distinguished itself among other species - on technique and innovative capacity and to these must be linked our hopes and our research efforts. Once again it will be the city that will allow us these developments and provide us with the solutions to break down physical walls and to make every type of barrier, even the invisible ones, surmountable.

\section{References}

Augé, M. (2007). Tra i confini: Città, luoghi, integrazioni [Between the borders: cities, places, integrations]. Milano: Bruno Mondadori. (In Italian).

Auge, M. (2008). Non-places: Introduction to an anthropology of supermodernity. London: Verso.

Ferraris, M., \& Paini, G. (2018). Scienza nuova: Ontologia della trasformazione digitale [New science: ontology of digital transformation]. Torino: Rosenberg \& Sellier. (In Italian). Retrieved from http://digital.casalini.it/9788878856653

Johnson, S. (2006). The Ghost Map: The story of London's most terrifying epidemic. New York: Riverhead.

Morin, E. (2015). Penser global Texte imprimé l'homme et son univers [Thinking globally Printed text Man and his universe]. Paris: Éditions Robert Laffont. (In French).

Selee, A. D. (2018). Vanishing frontiers: The forces driving Mexico and the United States together. New York,: PublicAffairs.

Sennett, R. (2018). Building and dwelling: Ethics for the city. Farrar.

Singapore Calling: MIT Senseable City Lab. (n.d.). Retrieved from Singapore Calling: MIT Senseable City Lab website: http://senseable.mit.edu/singapore-calling

West, G. (2017). Scale. London: Weidenfeld \& Nicolson.

Winslow, D. (2019). The border. New York: William Morrow \& Company. 
Журнал Фронтирных Исследований. 2021. No 1 | ISSN: 2500-0225

Xu, Y., Belyi, A., Santi, P., \& Ratti, C. (2019). Quantifying segregation in an integrated urban physical-social space. Fournal of The Royal Society Interface, 16(160), 20190 536. doi: 10.1098/rsif.2019.0536

\section{Список литературы}

Augé, M. (2007). Tra i confini: Città, luoghi, integrazioni [Between the borders: cities, places, integrations]. Milano: Bruno Mondadori. (In Italian).

Auge, M. (2008). Non-places: Introduction to an anthropology of supermodernity. London: Verso.

Ferraris, M., \& Paini, G. (2018). Scienza nuova: Ontologia della trasformazione digitale [New science: ontology of digital transformation]. Torino: Rosenberg \& Sellier. (In Italian). Retrieved from http://digital.casalini.it/9788878856653

Johnson, S. (2006). The Ghost Map: The story of London's most terrifying epidemic. New York: Riverhead.

Morin, E. (2015). Penser global Texte imprimé l'homme et son univers [Thinking globally Printed text Man and his universe]. Paris: Éditions Robert Laffont. (In French).

Selee, A. D. (2018). Vanishing frontiers: The forces driving Mexico and the United States together. New York,: PublicAffairs.

Sennett, R. (2018). Building and dwelling: Ethics for the city. Farrar.

Singapore Calling: MIT Senseable City Lab. (n.d.). Retrieved from Singapore Calling: MIT Senseable City Lab website: http://senseable.mit.edu/singapore-calling

West, G. (2017). Scale. London: Weidenfeld \& Nicolson.

Winslow, D. (2019). The border. New York: William Morrow \& Company.

Xu, Y., Belyi, A., Santi, P., \& Ratti, C. (2019). Quantifying segregation in an integrated urban physical-social space. Fournal of The Royal Society Interface, 16(160), 20190536 . doi: 10.1098/rsif.2019.0536 